\author{
Agnieszka Szpak \\ Nicolaus Copernicus University, Poland \\ ORCID: https://orcid.org/000-0001-7601-1230 \\ e-mail: aszpak@umk.pl
}

\title{
A Comparison of Nisga'a Self-Government and International Standards of Indigenous Self-Determination
}

\begin{abstract}
The paper concentrates on the right to self-determination of indigenous peoples on the basis of the Nisga'a Nation. The author analyzes the most important provisions of the Nisga'a Final Agreement, in particular those envisaging self-determination of the Nisga'a Nation. Then the author briefly examines the Nisga'a Constitution which may be regarded as a means to implement the Nisga'a Final Agreement. It shows how the Nisga'a selfgovernance model fits into the provisions on self-determination of indigenous peoples. The thesis of this paper is that the Nisga'a self-governance is consonant with international legal standards expressed in the UN Declaration on the Rights of Indigenous Peoples. Nisga'a selfgovernment model is much more than just cultural autonomy: it actually amounts to political autonomy. This subject is worth exploring because it may serve as a pattern to be followed with reference to other indigenous peoples, not only in Canada.
\end{abstract}

Keywords: indigenous peoples, Nisga'a Nation, right to self-determination, self-governance

\section{Introduction}

Nisga'a constitute about 6000 people living in Canada, in the northern part of British Columbia. Nisga' Nation means 'the collectivity of those aboriginal people who share the language, culture, and laws of the Nisga'a Indians of the Nass Area, and their descendants' (Nisga'a Final Agreement, 1999, Chapter 1, Definitions). In 1995 Nisga'a Tribal Council was established with the aim to resolve the Nisga'a land claims which was necessary to the political development of the Nisga'a (Svenesson, 2002, p. 14). For a long time, Nisga'a actively fought for their political rights. These efforts were crowned with the conclusion of the 
Nisga'a Final Agreement on 27 April 1999. In 1999 the treaty was ratified by the legislature of British Columbia, and in 2000 - by the Canadian government. It came into effect on 11 May 2000 , making Nisga'a a self-governing indigenous nation within the Canadian federation, in accordance with the 1982 Canada Constitutional Act, Section 35. The Agreement is the first modern land claims treaty also concerning self-government (Hoffman \& Robinson, 2010, pp. 387, 388, 392). The treaty recognizes Nisga' a lands and their right to self-determination. The Agreement was negotiated between the Nisga' a Nation, the Government of Canada and the Government of British Columbia who subsequently became its Parties. As it is showed below, Nisga'a have their own government, constitution, laws, jurisdiction, courts, citizenship, police and self-governance in their villages.

Even though this Agreement has not been concluded between states, it is legally valid and binding. First of all, the Vienna Convention on the Law of Treaties (1969) is applicable only to treaties concluded between states, but this does not mean that entities other than states cannot conclude international agreements (Art. 3 of the Vienna Convention). Secondly, according to Art. 37 of the UN Declaration on the Rights of Indigenous Peoples, 'indigenous peoples have the right to the recognition, observance and enforcement of treaties, agreements and other constructive arrangements concluded with states or their successors and to have states honor and respect such treaties, agreements and other constructive arrangements' (2007).

After this short introduction section 2 concentrates on the right to self-determination in general in order to briefly outline the meaning and scope of this concept. This serves as a background for more advanced and specific considerations. Then section 3 analyzes the most important provisions of the Nisga'a Final Agreement, in particular those envisaging self-determination of the Nisga'a Nation and section 4 refers to the Nisga'a Constitution which may be regarded as a means to implement the Nisga'a Final Agreement. Section 5 shows how the Nisga'a self-governance model fits into the international standards on self-determination of indigenous peoples - recognized above all in the UN Declaration on the Rights of Indigenous Peoples (hereinafter: UNDRIP). Finally, Concluding Remarks summarize the paper and indicate to the recommendable character of the Nisga'a selfgovernance. The following research questions may be asked: Is the Nisga'a model of selfdetermination in agreement with international legal standards codified in UNDRIP? Hence, can the Nisga'a Final Agreement contribute to implementation of the latter? The thesis of this paper is that the Nisga'a self-governance is consonant with international legal standards expressed in UNDRIP. It is much more than just cultural autonomy: it actually amounts to political autonomy. This subject is worth exploring because, as is rightly argued by e.g. Dawid Bunikowski and Patrick Dillon (2017, p. 51), 'Canada is by no means a world leader in the way it treats indigenous peoples'. The example of the self-governance of the Nisga'a Nation confirms this statement. It is worth examining, especially so as this example may serve as a pattern to be followed with reference to other indigenous peoples, not only in Canada. The examined issues of self-determination and self-governance are legal but also 
political concepts. In this case law serves to realize a political goal of political autonomy of a certain community - Nisga'a people. As a political and legal category self-determination/ self-governance means that Nisga' a people are part of the decision-making process, also in political matters, matters that affect them.

The paper builds on the existing literature in the field of indigenous peoples and their right to self-determination as well as on the legal documents such as Nisga'a Final Agreement (1999), Nisga'a Constitution (1998) and UNDRIP (2007). An interpretative guide Understanding the Nisga'a Treaty of 1998 was also of assistance in writing this paper. An excellent website of the Nisga'a Lisims Government was also a very valuable source of information (http:// www.nisgaanation.ca/). As to the literature there are publications on the rights of indigenous peoples in general, including the right to self-determination, such as those by Baer (2005), Barsh (1994), Gunn (2011) or Manarella (2001-2002) that are referenced in this paper. There are also publications that are devoted to a particular case of the Nisga'a self-government such as Adams (1999), Ferguson (1999), Gibson (1999) or Hofmann and Robinson (2010). Svensson (2002) compares the Nisga'a and the Saami self-government.

The research method adopted is that of legal-institutional analysis which is used to interpret textual material and decipher its meaning. The institutional and legal analysis includes an examination of the content of legal acts and other mentioned documents and in the subsequent considerations.

\section{The Right to Self-Determination in General}

The principle of self-determination is one of the fundamental principles of international law; it is envisaged in the common Art. 1 of the International Covenant on Civil and Political Rights and International Covenant on Economic, Social and Cultural Rights (1966) states that '[a]ll peoples have the right of self-determination. By virtue of that right they freely determine their political status and freely pursue their economic, social and cultural development'. Principle of self-determination is also referred to in Art. 1 (2) of the UN Charter (1945).

Self-determination has an internal and external aspect. The first one encompasses the right of the people to realize their rights, interests, aspirations and sovereignty within the existing state, whereas the second refers to the right to create a separate state (hence, to secession). Internal aspect of self-determination does not raise much controversies but the external one is very controversial and - generally - does not include the right to secession of peoples without the consent of the existing state (Kałduński, 2010, p. 444). The right to self-determination and secession are not identical which means that only exceptionally self-determination is exercised in the form of secession (Białocerkiewicz, 2007, p. 154). As a fundamental principle of international law the principle of self-determination should be examined in the context of the whole corpus of international law, i.e. in the context of all the principles of international law reckoned in the UN Charter such as prohibition 
of the use of force, respect for territorial integrity or for human rights (Kałduński, 2007, p. 449). The principle of territorial integrity is of special significance as it clearly opposes self-determination in the form of secession. Secession means detachment of a part of the state territory in order to create a new state (for more details see Crawford, 1979, pp. 247-270) or to join another state. International law does not proscribe secession nor does it contain a right to secession. As Jure Vidmar (2014) argues, 'international law is actually neutral on the question of unilateral secession. This means that unilateral secession is neither prohibited nor an entitlement'. James Crawford (2007), representing the majority view, claims that international law allows for secession only with the consent of the existing state. The general conclusion is that 'state practice is very reluctant to acknowledge a right to secession, since states fear that their own territorial integrity might be endangered by an empowerment of secessionist groups' (inter alia Spain, Russia, China) (Marxsen, 2014). In this context one may notice that UN General Assembly resolution 1514 (XIV) of 1960 Declaration on the Granting of Independence to Colonial Countries and Peoples - states that ' a]ny attempt aimed at the partial or total disruption of the national unity and the territorial integrity of a country is incompatible with the purposes and principles of the Charter of the United Nations' (para. 6). A similar provision may be found in resolution 2625 (XXV) of 1970 (Declaration on Principles of International Law concerning Friendly Relations and Co-operation among States in accordance with the Charter of the United Nations). Those provisions specify that self-determination should be realized first of all in its internal aspect, for example in the form of autonomy within the existing state, hence the preference for internal form of self-determination is prevalent. However, some scholars point to an exception to the requirement of consent, namely that of remedial secession (separate opinion of Judge Cançado Trindade to the ICJ advisory opinion on the Accordance with international law of the unilateral declaration of independence in respect of Kosovo, para. 176; Cassese, 2005 , pp. 91, 68). This, however, is still the view of the minority of international lawyers and political scientists. Prospect of remedial secession has been endorsed by the Supreme Court of Canada in the case of Reference re Secession of Quebec (paras. 132-133, 138). Accordingly, such a secession would be legal when the population (peoples) is under the occupation, foreign domination, is exploited or their human rights are blatantly violated, which in fact amounts to their right to internal self-determination being violated. Chris Borgen (2008) explains this in this way:

any attempt to claim a legal secession - that is, where secession trumps territorial integrity - must at least show that:

(1) the secessionists are a "people" (in the ethnographic sense);

(2) the state from which they are seceding seriously violates their human rights; and

(3) there are no other effective remedies under either domestic law or international law. 
After these introductory and general remarks on the right to self-determination, the next section continues with the specific example of implementation of this right in the form of autonomy or self-government, namely the Nisga'a case.

\section{Nisga'a Self-Government}

\subsection{Outline of the main Final Agreement provisions}

As indicated by Ross Hoffman and Andrew Robinson, unlike the very concise treaties signed between 1871 and 1921 that were marked only by numbers, the Nisga'a Final Agreement is a comprehensive document - its 251 pages cover all the aspects of self-government in detail. By the Agreement, the Nisga'a hold the right to self-government and are authorized to manage the traditional Nisga' a lands and resources. They enjoy the benefits and rights of all Canadian citizens, and they still are an Aboriginal People as stated in Sections 25 and 35 of the Canadian Constitution Act from 1982. The Canadian Charter of Rights and Freedoms is applicable to the Nisga'a Government, and Nisga'a citizens as well as other persons living on Nisga'a lands are subject to provincial and federal laws. The rights of the Nisga'a people are defined by the Final Agreement as recognized and affirmed by Section 35 of the Constitution of Canada (Hoffman \& Robinson, 2010, p. 392). In this vein sections 8 and 9 (Chapter 2) of the Final Agreement state that all matters within Nisga'a Government's authority, must be concordant with the Canadian Charter of Rights and Freedoms, while preserving the free and democratic nature of Nisga'a Government as delineated in the Agreement.

The Agreement delineates the structure and mandate of Nisga'a self-rule: the central government of the people is Nisga'a Lisims Government, while the local communities are administered by four Village Governments and three Urban Locals. Nisga'a system is representational democracy, with all three elements of the government elected by voting, each of the Nisga'a citizens having one vote. Under the Agreement, the Nisga'a Government holds the power to pass laws necessary to exercise its authority and meet its responsibilities (Hoffman \& Robinson, 2010,pp. 392-393). Such laws may concern Nisga'a citizenship, language and culture, property in their lands, peace, safety and public order, transportation and traffic, employment, education, health and social services, and issues related to family and children, such as marriage solemnization, child custody and adoption. However, it ought to be noted that Nisga' a people and lands are still subject to the laws of the province and the federation. The Agreement authorizes the Nisga'a Government to establish their own police, court and correctional institutions on their territory (Hoffman \& Robinson, 2010, p. 394).

The Agreement returned to the Nisga'a $1930 \mathrm{~km}^{2}$ of the Crown land (earlier controlled by the province) as well as $62 \mathrm{~km}^{2}$ of Indian reserves (section 2, Chapter 3). This land is the property of the Nisga'a Nation in the same way other landowners hold ownership of their lands. However, unlike other owners, Nisga'a people also own all resources located under the surface of their lands (sections 3, 19-20, Chapter 3). All forest resources in these lands belong 
to the Nisga'a (section 3, Chapter 5). Forest management standards can be implemented by the Nisga'a Government if they are comparable to or higher than British Columbia standards (section 8 , Chapter 5 ). The Nisga' a people are allowed to hunt grizzly bear, moose and mountain goat (a specified amount for domestic purposes) within the Nass Wildlife Area, a wildlife management area set by the provincial authorities that includes also the Agreement-defined Nisga'a lands. The Nass Wildlife Area is co-managed by the province and the Nisga'a; hunts outside this area are regulated by provincial laws (sections 12-15, Chapter 9). The Nisga'a can barter or trade wildlife game or its parts within their community or with other indigenous groups (section 68, Chapter 9) (Nisga'a Final Agreement, 1999; Hoffman \& Robinson, 2010, p. 394). The provisions of the Nisga'a Final Agreement refer also to the matters of Nisga'a heritage and culture. According to section 7 (Chapter 2) it is the right of Nisga' a citizens to practice their culture, and to use the Nisga' language, as consistent with the Agreement (Nisga’a Final Agreement, 1999; Hoffman \& Robinson, 2010, p. 395).

Hofmann and Robinson (2010, p. 395) rightly highlight that overall, while other citizens of Canada may consider the Final Agreement to be generous, the Nisga'a people had to make significant concessions during the negotiations. For example, the area of the lands they claimed as their traditional territory was approximately $24,000 \mathrm{~km}^{2}$; the Treaty gave them the ownership of mere 8 per cent of that.

\subsection{Political structure of the Nisga'a self-government}

The political structure of the Nisga' a self-government consists of three elements. Its central government is called the Nisga'a Lisims Government. On the local level, the four Nisga'a communities have their own Village Governments (section 2, Chapter 11). These two levels receive guidance from the third body, the Council of Elders, which serves as a bridge between tradition and modernity. Such arrangement ensures that the current policies are conformant with the customary Nisga'a laws, and that Ayuukhl, the traditional knowledge, is kept and practiced (section 9 (i), Chapter 11) (Svensson, 2002, pp. 23-24).

The provisions of the Nisga'a Final Agreement state that the Nisga'a have the right to develop and implement their own system of justice, based on Nisga'a laws. The legislative branch of the Nisga'a Lisims Government, Wilp Si'ayuukhl Nisga'a, is entitled to create laws and establish a Nisga'a Court. Still, as Canadian citizens, the Nisga' a have to follow the Canadian common law in cases of serious criminal offences, and comply with the Canadian Charter of Rights and Freedoms (Svensson, 2002, p. 25).

Chapter 11 of the Final Agreement describes the self-government of the Nisga'a Nation: its establishment, basic structures, areas of jurisdiction and the rules on which interactions between Nisga' a laws and provincial and federal laws are based. The Final Agreement is the first agreement of this kind that clearly describes self-government as an integral element of the treaty. This ensures certainty as to Nisga'a rights to self-government, law making authority and relations with federal and provincial regulations. The exercise of jurisdiction 
and authority by Nisga'a is supposed to evolve with time (Understanding the Nisga'a Treaty, 1998, p. 51).

Both the Nisga'a Nation and each of the four Nisga'a villages are considered separate and distinct legal identities, each of them with the rights, powers, capacity and privileges of a natural person and able to:

- conclude contracts and agreements

- obtain and keep property, or an interest in one, as well as sell such a property or otherwise dispose of it;

- spend, borrow, raise or invest money;

- sue and be sued;

- do everything necessary for or supportive of exercising its rights, powers and privileges (section 5, Chapter 11 of the Final Agreement).

It should be clarified that 'Nisga'a Government' can refer both to Nisga'a Lisims Government and Nisga'a Village Governments. The majority of jurisdictions is clearly assigned either to Nisga'a Lisims Government or Nisga'a Village Governments. The text of the Final Agreement specifies which level of Nisga'a Government is responsible for a particular matter. Nisga'a Lisims Government represents the Nisga'a Nation and each Nisga'a Village Government represents its village (sections 7-8, Chapter 11). Nisga'a Lisims Government comprises all four of the Village Governments, one or more representative of each Nisga'a Urban Local, and at least three officers - the President, the Chairperson and the Secretary-Treasurer elected in a general election by the Nation. The members of each Village Government are elected in accordance with Nisga'a Constitution. Nisga'a Urban Locals will continue to operate in Greater Vancouver, Prince Rupert-Port Edward and Terrace so as to let Nisga'a citizens living outside the Nass Area participate in the Nisga'a Lisims Government. Government elections must follow the rules set in Nisga'a Constitution and law (sections 12-13, Chapter 11) (Understanding the Nisga'a Treaty, 1998, p. 52).

It is recognized that certain decisions of Nisga'a Government can affect non-Nisga'a residents of Nisga'a villages who include e.g. spouses and workers as well as people living on the fee simple properties excluded from Nisga'a lands. Such individuals will be consulted by the Nisga'a Government on any matters that significantly and directly influence them. In cases when non-Nisga'a residents are significantly and directly affected by the activities of a Nisga'a Public Institution, e.g. a school board or a health board, the Government will offer them opportunity to participate by such measures as making representations, voting or running for the office, having guaranteed seats at a given institution etc. (sections 19-23, Chapter 11) (Understanding the Nisga'a Treaty, 1998, p. 53).

In most cases, Nisga'a laws will operate as parallel to provincial and federal laws, as opposed to the traditional system with exclusive jurisdiction of the government. Therefore, an analysis should be made for each area of jurisdiction as to what will happen if there is a discrepancy between a valid Nisga'a law and a valid provincial or federal law. Such differences can appear in two forms. In some cases, the laws are 'inconsistent', i.e. the citizens are 
required to do different things. In other, the laws are 'in conflict', i.e. if a citizen follows one law, they break the other. The Agreement describes which laws prevail for which subject matter. If Nisga'a laws prevail, the question is whether the laws are inconsistent or in conflict. If provincial and federal laws prevail, the question is whether the laws are in conflict. To see which laws take precedence in which situation, the Agreement must be read in detail. Generally speaking, Nisga'a laws predominantly apply to internal matters, and the provincial or federal laws prevail when the matters are subject to provincial or national standards and laws (for example see sections 38, 40, 43, 45, Chapter 11) (Understanding the Nisga'a Treaty, 1998, p. 54).

The laws that can be made by Nisga'a Government pertain to its administration, management and operation, e.g. establishing Nisga'a Public Institutions, setting out the of powers, duties and remunerations of people working in the said institutions, financial administration as well as various types of elections. Another area where Nisga'a Lisims Government is entitled to make laws is establishing, joining, dissolving or naming of Nisga'a villages in Nisga'a territories and Urban Locals (section 34, Chapter 11). Nisga'a Lisims Government can make laws regarding the matters of Nisga'a citizenship (section 39, Chapter 11) and of preservation, promotion and development of Nisga'a culture and language, e.g. laws concerning such matters as teaching Nisga'a language or use, reproduction and representation of Nisga'a cultural symbols (section 41, Chapter 11).

Nisga'a Lisims Government is entitled to make laws pertaining to regulation and administration of Nisga'a territories, e.g.

- Management, use, zoning, planning and development of Nisga'a Lands;

- Setting up and operating a land title or land registry system for the Nisga'a Lands where provincial legislation on land title is not applicable;

- Regulations, permits and prohibitions for businesses, trades and professions to operate on Nisga'a Lands, including licence and other fees;

- Designing Nisga'a Lands as private lands or village lands;

- Expropriations of estates or businesses located in Nisga'a lands for public works and purposes (section 47, Chapter 11).

Nisga'a Government has the right to make laws concerning regulating, controlling and prohibiting actions, activities etc. on Nisga'a Lands and - with certain reservations - on lands submerged within Nisga'a Lands, which are or may be a nuisance or act of trespassing, or which endanger public order, safety, health or peace. For the sake of clarity the Agreement adds that 'Nisga'a Government authority does not include authority in respect of criminal law' (sections 59-61, Chapter 11).

\subsection{Administration of justice}

Chapter 12 of the Final Agreement establishes the rules for Nisga'a Nation on policing, correction services and Nisga'a Court. It generally attempts to create structures integrated 
with the provincial and federation judiciary systems, while maintaining balance between the necessary local involvement and impracticality of entirely separate structures (Understanding the Nisga'a Treaty, 1998, p. 64).

According to sections 1 and 2 of the mentioned Chapter, the Nisga'a Government will be authorized to provide policing in Nisga' Lands. If they chose so, they may pass laws establishing a Nisga' a police board and police service, or contract the provincial police service or other police forces - or combine these two solutions. The Parties consider that in any form, the Nisga' a police should respond to the priorities and needs of the Nation, to bear the full spectrum of police authorities and responsibilities as well as to participate in administering justice, maintaining social order and ensuring public security (section 2, Chapter 12) (Understanding the Nisga'a Treaty, 1998, p. 64). Nisga'a police officers will have the same powers, privileges, duties, responsibilities and liabilities as members of other police forces according to Canadian law. However, although their authority will extend to the whole area of British Columbia, in ordinary situations it will be restricted to Nisga' Lands, unless there is an emergency or they receive a request for assistance from a corresponding service (section 13, Chapter 12) (Understanding the Nisga'a Treaty, 1998, p. 65).

Importantly, the Nisga'a Lisims Government may establish a Nisga'a Court. In such a case the Nisga'a Government is obliged to make laws ensuring compliance with generally understood principles of impartiality, independence and fairness, supervision of judges, and ways to appeal from the Nisga'a Court decisions to British Columbia courts (sections 30,33, Chapter 12). The Agreement contains general provisions concerning appeals to the Supreme Court of British Columbia and then, following the provincial and federal laws, to the Supreme Court of Canada (section 45, Chapter 12) (Understanding the Nisga'a Treaty, 1998, p. 66).

\section{Nisga'a Constitution}

Part of the ratification of the Final Agreement by the Nisga' people was adopting a Constitution defining the rights and freedoms as well as terms of self-governance of Nisga'a citizens. Constitution was ratified in October 1998. It regulates such issues as Nisga' a rights, lands and resources including the structure and functions of the Nisga'a Lisims Government, Nisga'a Village Governments and other institutions as well as dispute resolution and public finance administration. Chapter 1 contains founding provisions. Among others it defines the Nisga'a Nation in exactly the same way as the Final Agreement (Art. 1 (1) of the Nisga'a Constitution). Art. 2 enumerates fundamental values of the Nisga'a Nation that are also at the basis of the Nisga'a Constitution. Examples include: 'Nisga'a cherish and celebrate the spirituality of our people, [...] Nisga'a honor the traditions of our ancestors, the authority of our Ayuuk, and the wisdom of our elders [and] Nisga'a respect the dignity of each person'. Art. 3 emphasizes the role and significance of the Nisga'a el- 
ders. According to the Constitution Nisga'a and English are the official languages of Nisga'a Government (Art. 4 (1)) and Nisga'a Government must encourage the use of the Nisga'a language and the practice of Nisga'a culture (Art. 4 (2)). The Constitution (1998) characterizes Nisga'a by their deep spiritual relationship with the lands and natural resources which together with Nisga'a culture, language and traditions explain what it means to be Nisga'a (Art. 5 (2)).

In accordance with Art. 6 (1) the Constitution is supreme law of the Nisga'a Nation, subject only to: (a) the Constitution of Canada, and (b) the Nisga' Treaty, which sets out the authority of Nisga'a Government to makes laws'. Paragraphs 2 and 3 add that

[t]he Canadian Charter of Rights and Freedoms applies to Nisga'a Government in respect of all matters within its authority, bearing in mind the free and democratic nature of Nisga'a Government [...] In the event of an inconsistency or conflict between this Constitution and the provisions of any Nisga'a law, the Nisga'a law is, to the extent of the inconsistency or conflict, of no force or effect.

If there are any doubts as to the validity of the Nisga'a law such a law may be challenged in the Supreme Court of British Columbia (Art. 7). Nisga'a citizens have political rights (Art. 11) and the right to enter, remain and leave Nisga' a lands (Art. 10). Political rights are linked to the voting rights. The latter mean that every Nisga'a citizen that is 18 years old - subject most of all to the residency requirements - may vote in Nisga a elections and run for an office in Nisga'a Government (Art. 12 (1)).

The Constitution established the Nisga'a Lisims Government (also envisaged in the Final Agreement) comprising five parts: the Executive of Nisga'a Lisims Government (Art. 31), Wilp Siayuukhl Nisga'a (a legislative branch of the Government, which may be treated as a kind of a parliamentary body), which together form the central level of government, local governments of the four Nisga'a villages (New Aiyansh, Gitwinsilkw, Laxgaltsap and Gingolx), three Urban Locals (of Vancouver, Terrace and Prince Rupert/Port Edward) and the Council of Elders (Arts. 25-27). The main task of the Urban Local is to be an intermediary and contact between Nisga'a Government and Nisga'a citizens living in Nisga'a Urban Local Area (in other words, in cities) (Nisga'a Constitution, 1998, Art. 26 (3)).

The administration of the Nisga'a Lisims Government is overseen by the Executive, consisting of the President, the Secretary-Treasurer, the Chairperson, the Chair of the Council of Elders, the Chief Councillors of the four Village Governments and three representatives of the urban locals (Nisga'a Constitution, 1998, Art. 36). The Council of Elders comprises Hereditary Chiefs (Simgigat), Hereditary Matriarchs (Sigidimhaanak) as well as other Nisga'a elders respected by their communities who hold hereditary titles. The Council's role is advising the Nisga'a Lisims Government on traditions of their people (Nisga'a Constitution, 1998, Art. 27; Hoffman \& Robinson, 2010, p. 397).

According with Art. 32, main competences of the Wilp Siayuukhl Nisga'a include: 
(a) making any law within the authority of Nisga'a Government, or the authority of Nisga'a Lisims Government, as set out in the Nisga'a treaty; (b) adopting any federal or provincial law in respect of a matter within the authority of Nisga'a Government, or Nisga’a Lisims Government, as set out in the Nisga'a Treaty; (c) passing a resolution proposing an amendment to this Constitution; and (d) passing a resolution proposing a question to be put to the Nisga'a Nation in a referendum (Nisga'a Constitution, 1998).

An executive arm of the Government is assigned a task of executing the power and responsibilities as defined in the Constitution or delegated to it by the Wilp Siayuukhl Nisga'a. It also represents the Nisga'a Nation in international/intergovernmental relations (Nisga'a Constitution, 1998, Art. 37 (c)).

\section{Indigenous Self-Determination - Is Nisga'a Model Consonant with UNDRIP?}

UN Declaration on the Rights of Indigenous Peoples (2007) is the most important, however non-binding, instrument on the rights of indigenous peoples. Still despite its formally nonbinding character, UNDRIP'consolidates the rights of indigenous peoples already recognized in other human rights instruments and through the jurisprudence of international human rights treaty bodies' (Conservation and indigenous peoples' rights. Report to the General Assembly, 2016). It is extremely important to stress that UNDRIP is not the source of the right to self-determination of indigenous peoples, it merely recognizes rights that inhere in indigenous peoples by way of their indigenous sovereignty dating back to long time before the emergence of states and conquest of indigenous territories. Jérémie Gilbert and Valérie Couillard (2009, pp. 30-31) point to the "pre-existing rights" [that] could have had some beneficial consequences for indigenous peoples: if their rights pre-existed the colonial legal regime, they might also survive it. This is exactly the kind of argument underlying all the claims of indigenous peoples to their rights. Those pre-existing rights since time immemorial belong to indigenous peoples but were taken from them by conquest and it is high time to recognize and realize them (Gilbert \& Couillard, 2009, pp. 30-31).

UNDRIP recognizes that indigenous peoples have a collection of rights: individual ones that persons have as members of the group and collective ones that belong to the group as a whole (in particular land rights) (Art. 1 of UNDRIP). Art. 3 refers to the right to self-determination of indigenous peoples which is defined as the ability freely to determine their political status and freely pursue their economic, social and cultural development'. Art. 4 expressis verbis recognizes the right to autonomy or self-governance in the exercise of the right to self-determination. Self-determination is linked to the right to autonomy or self-governance in matters relating to internal and local affairs of indigenous peoples (Kingsbury, 1992, pp. 501-503). This formula indicates that self-determination should be exercised first of all in the form of autonomy. Moreover, UNDRIP specifies that 
[n]othing in this Declaration may be interpreted as implying for any State, people, group or person any right to engage in any activity or to perform any act contrary to the Charter of the United Nations or construed as authorizing or encouraging any action which would dismember or impair, totally or in part, the territorial integrity or political unity of sovereign and independent States (Art. 46).

Despite this formula, which seems to give priority to territorial integrity of a state over the right to secede, numerous states fear that recognizing the right of indigenous peoples to self-determination may result in secession. Those worries are however unjustified as majority of indigenous peoples do not want to create a separate state but be able to make free and independent decisions in their own matters (Okafor, 2002, pp.41-70; Baer, 2005, p. 257; Gunn, 2007, p. 58). In order not to leave this statement unfounded it is worth giving voice to the indigenous peoples themselves: for example, the President of the Ainu (indigenous peoples in Japan) Association Giichi Nomura stated that:

[t]he right to self-determination was not a threat to the national unity or the territorial integrity of Member States. What the Ainu sought was a high level of autonomy based on the fundamental values of "co-existence with nature" and "peace through negotiation". They did not seek to create new States with which to confront those already in existence (Barsh, 1994, p. 41).

Kenneth Deer, Mohawk and former co-chair of the Indigenous Peoples' Caucus, adds delineating important components of self-determination - that '[a]ll our rights either flow from or are linked to our right of self-determination. These include our right to land, our right to natural resources, our right to our language and culture, our right to our songs...' (Gunn, 2011, p. 10). Consequently, indigenous peoples are entitled to 'maintain and strengthen their distinct political, legal, economic, social and cultural institutions, while retaining their right to participate fully, if they so choose, in the political, economic, social and cultural life of the State' (Art. 5 of UNDRIP).

It is also worth adding that external self-determination is not only limited to secession. It may also encompass participation of indigenous peoples in international conferences and work of international organs and institutions (Fitzmaurice, 2009, p. 144), for example in the UN Permanent Forum on Indigenous Issues (on line), the Arctic Council where the Sami are taking part as permanent participants (Metcalf, 2003-2004, pp. 116-119; Koivurova, 2008, p. 286), UN Open-Ended Working Group on the Declaration on the Rights of Indigenous Peoples. Indigenous peoples also took part in the creation of the ILO Convention 169 on Indigenous and Tribal Peoples in Independent Countries as well as in the Organization of American States' Declaration on the Rights of Indigenous Peoples. According to Brenda Gunn (2011,pp. 59-60), 'through their active participation in the drafting and negotiation 
process, various Indigenous peoples have been able to articulate their rights in a way that is meaningful to them' (Abate \& Kronk, 2013, pp. 42-48).

Concrete examples of implementing the right to self-determination as self-governance or a kind of autonomy are Sami parliaments in Sweden, Norway and Finland (here it is rather cultural autonomy), Greenland self-government or Nisga'a and Nunavut territories in Canada.

Autonomy may be built on contemporary indigenous political institutions, for example the Sami Parliaments in the Nordic States. It may also be designed as autonomy based on some territorial arrangements including the ancestral indigenous territories such as Comarca's Kuna Yala in Panama. Another form of autonomy involves regional autonomy within the state, such as Nunavut territory in Canada (Magnarella, 2001-2004,p.442) or the Nisga'a territory in Canada (Report of the Special Rapporteur on the situation of human rights and fundamental freedoms of indigenous people, Rodolfo Stavenhagen. Addendum. Mission to Canada, 2004, para.27). Autonomy does not have to be shaped as a territorial one encompassing parts of the territory authorized to self-governance, but it may also include the authorization of indigenous peoples to enact their own laws, to have their own courts and use their lands according to their customs, traditions and needs. Although territorial autonomy is usually more far reaching then mere cultural autonomy and is frequently accompanied by political autonomy like in the case of the Nisga' a Nation.

In the case of the Nisga' - and considering the background remarks on the meaning of autonomy - there exist self-governance bodies such as the central government (Nisga'a Lisims Government) with its legislative and executive arms as well as local governments (four Village Governments) and three Urban Locals. This corresponds to the Art. 5 of UNDRIP on maintenance and strengthening of indigenous peoples distinct political institutions and Art. 18 guaranteeing the indigenous peoples the right to participate in the process of decision-making in matters that would affect their rights. Such participation should take effect through their own representatives chosen in accordance with indigenous (here the Nisga'a's) procedures. The same provision also recognizes the indigenous peoples' right to maintain and develop their own decision-making institutions. The Nisga' people have the voting rights in their self-governance institutions which corresponds to the right to effective participation in matters that affect them and to decide on the composition of their own self-government bodies. In this context it is worth mentioning that in case of a conflict of laws (federal and Nisga'a laws), the Nisga'a laws predominantly apply to internal matters while the federal laws apply to matters of provincial and national character. This solution proves that in internal matters the Nisga a can make their own decisions which accords with their political autonomy.

Nisga'a Lisims Government is entitled to pass laws necessary to exercise its authority, for example in the areas of citizenship, language, culture, safety, public order, education or health. Here the provisions most directly relevant are Arts. 8, 9, 13, 21, 24, 31 and 33 of UNDRIP, but also Art. 28 of ILO Convention 169 (an obligation to promote and develop indigenous 
languages). As mentioned, Nisga'a language is recognized as the official language of the Nisga'a Government. Art. 9 of UNDRIP states that 'Indigenous peoples and individuals have the right to belong to an indigenous community or nation, in accordance with the traditions and customs of the community or nation concerned' which amounts to the Nisga'a nation's right to determine their own citizenship. The Nisga'a citizenship is connected with the right of indigenous peoples to determine their own identity or membership (UNDRIP, 2007, Art. 33).

Art. 8 prohibits forced assimilation and destruction of the indigenous culture. Other provisions relevant for the maintenance and development of the indigenous culture and languages instruct that indigenous peoples are entitled to revitalize, use, develop and transmit to future generations their languages, histories, philosophies, literatures and oral transmissions (Art. 13) and to maintain, control, develop and protect indigenous culture and traditional cultural expressions (Art. 31).

Arts. 21 and 24 of UNDRIP guarantee the right of indigenous peoples to the improvement of their economic and social conditions, including their health and the right to their traditional medicines and health practices. Hence, on the one hand a state should ensure this right without discrimination and, on the other, the indigenous peoples may make their own decisions in this regard. The Nisga'a self-government model complies with all of those provisions.

Very important provisions most directly pertaining to the Nisga'a self-government model are those on land rights. Nisga'a people are entitled to their lands and natural resources and the Nisga'a Government can regulate, control and prohibit activities taking place on Nisga' a lands such as mining or other industrial or developmental projects. These rights reflect Arts. 10,23, 26 and possibly 28, 29 and 32 of UNDRIP (and Art. 14 of ILO Convention 169 on indigenous land rights). These provisions prohibit forcible removal of indigenous peoples from their lands. Art. 26 recognizes the indigenous peoples' rights to their lands and resources. They can own, use, develop and control their lands and resources, the ones they traditionally owned, used or occupied. UNDRIP stipulates the right of indigenous peoples to redress (restitution or - if not possible - just, fair and equitable compensation for confiscation, occupation or use of indigenous lands without their free, prior and informed consent) (Art.28). Accordingly, indigenous peoples (here: the Nisga'a) are entitled to the conservation and protection of the productive capacity of their lands and of the environment (Art. 29. 1). Nisga'a own their lands and natural resources (including forests), also resources located under the surface of their lands (e.g. precious metals, coal, and petroleum). It is worth adding that according to the ILO Convention 169, there is a possibility that the state will retain the ownership of mineral sub-surface resources, but even in this case there should be procedures to consult indigenous peoples in order to assess whether exploration or exploitation of such resources will negatively affect them (Art. 15). The Nisga'a self-governance model guarantees them the right to own also sub-surface resources. Moreover, spiritual relationship Nisga' a's, as well as those of other indigenous peoples', with their lands and resources is recognized in 
Arts. 25 of UNDRIP and Art. 13 of ILO Convention 169. As mentioned, the same provision is included in the Nisga'a Constitution.

Nisga'a lands are inherently linked with their development. Accordingly, Art. 32.1 UNDRIP acknowledges their right 'to determine and develop priorities and strategies for the development or use of their lands or territories and other resources'. In this context one may add Art. 23, which guarantees the right of the indigenous peoples to determine and advance priorities and plans for implementing their right to development. To complete the picture, also Art. 7 of ILO Convention 169 ensures the right of indigenous peoples to determine their own development priorities. Nisga' a people have the right to hunt on the Nass Wildlife Area, which is consonant with their right to traditional livelihoods from Art. 20 of UNDRIP (and Art. 23 of ILO Convention).

Nisga'a people have their own police and court, which constitutes application of their right to develop their own justice system. Nisga'a system of justice is integrated with the provincial and federal judicial system. These regulations are consonant with Arts. 5 and 34 of UNDRIP. The former ensures the right to maintain and strengthen separate indigenous legal and political institutions such as their courts and police, while the latter expressly refers to the indigenous justice system that should be maintained and developed (although they have to conform to human rights standards).

The comparison of the provisions of the Nisga'a Final Agreement and the Nisga'a Constitution with UNDRIP shows coherence between them. While UNDRIP sets minimal standards, there is no obstacle in recognizing more indigenous rights or in expanding their scope. One can conclude that Nisga'a self-governance model is consonant with the UNDRIP standards.

\section{Concluding Remarks}

To conclude I would like to emphasize the significance of autonomy of indigenous peoples. Nuuk Conclusions and Recommendations on Indigenous Autonomy and Self-Government of 1991 stress that autonomy is essential for indigenous peoples, principally as a fundamental condition of their equality, dignity, freedom from discrimination and full respect for their human rights (Art. 4). Autonomy is also beneficial for environmental protection and maintaining the ecological balance necessary to ensure sustainable development (Art. 6) (Loukacheva, 2005, p. 14). Implementation of the right to self-determination is essential to the survival of indigenous peoples and their social, political, economic and cultural welfare and development.

There is also a set of documents prepared and adopted by representatives of the indigenous peoples in which they call for the implementation of their right to self-determination. For instance, in the Earth Charter adopted at the 1992 Kari Oca conference, indigenous peoples demand respect for their right to self-determination (paragraph 14), their traditional way of life (paragraph 16) and their right to development according to their cultural 
practices and economic and ecological vitality (paragraph 62). In powerful words, the Earth Charter states that Western concepts of development led to the destruction of the indigenous lands. Consequently, indigenous peoples reject the current definition of economic development (paragraph 66). The Seattle Declaration of 1999 called for alternative models of development, demanding recognition and respect for indigenous peoples rights to lands and natural resources, and to continue their practices in the field of sustainable agriculture and management of natural resources.

The rights of the Nisga'a Nation as recognized in the Nisga'a Final Agreement and then specified in the Nisga'a Constitution amount to the regional and political autonomy. On that basis Nisga'a people are guaranteed land rights and the right to make decisions and enact laws in their internal affairs such as citizenship, culture, public order, safety, police, property, employment, education or courts. This model of self-determination combines traditional and modern elements, the former one being exemplified by the recognition of the role of elders and the latter by the division and balance of powers characteristic for modern representational democracy. As Patrick Dillon and Dawid Bunikowski (2017, p. 54) rightly claim, "[a]ll these provisions must be understood in the context of delegation of power and decentralization [...] or legal-pluralistic processes of recognition of diversity and differences". There are actually two levels of Nisga'a government - the central one: Nisga'a Lisims Government and local one: at the level of villages and urban area. The Nisga'a Final Agreement 'allows the Nisga'a people to govern themselves in a way comparable to a municipal government' (Ferguson, 1999, p. 62).

The questions asked in the introduction to this paper may be answered in the following way: the Nisga'a self-governance (in other words, self-determination model) is consonant with the provisions of the UN Declaration on the Rights of Indigenous Peoples and it shows how self-determination of indigenous peoples should be implemented. It is an example to be followed as it recognizes the rights and interests of indigenous peoples on the scale unprecedented, not only in Canada but globally. Naturally, it does not mean that the model adopted with reference to the Nisga'a is perfect; it suffices to mention the surface of Nisga'a lands was far away from what belong to the Nisga'a. Nevertheless, Nisga'a self-governance based on the Nisga'a Final Agreement and Nisga'a Constitution is a model that should be implemented globally as it - so far - recognizes the inherent rights and sovereignty of indigenous peoples most fully. The Nisga'a Final Agreement together with the Nisga'a Constitution contribute to the implementation of UNDRIP or, more broadly speaking, international standards on the rights of indigenous peoples. As a result of all the considerations in this paper it seems that the thesis of the paper has been confirmed. One may argue that the Final Agreement together with the Nisga'a Constitution fit into 'concept of empowerment, the general idea that if indigenous peoples are given the proper legal and material resources they will solve their own problems' (Gibson, 1999, p. 4; Adams, 1999, p. 1). 


\section{References:}

Abate, R., \& Kronk, E. (Eds.) (2013). Climate Change and Indigenous Peoples: The Search for Legal Remedies. Cheltenham: Edward Elgar Publishing.

Adams, S. (1999). "Understanding the Nisga'a Agreement and Looking at Alternatives". Public Policy Sources, 17, 1-37.

Advisory Opinion of the African Commission of Human and Peoples' Rights on the UN Declaration on the Rights of Indigenous Peoples. (2007). (2020, February 6). Retrieved from: http:// www.achpr.org/files/special-mechanisms/indigenous-populations/un_advisory_opinion _idp_eng.pdf.

Baer, L. A. (2005). 'The Rights of Indigenous Peoples - A Brief Introduction in the Context of the Sámi”. International Journal on Minority and Group Rights, 2/3, pp. 245-267.

Barsh, R. L. (1994). "Indigenous Peoples in the 1990s: From Object to Subject of International Law?". Harvard Human Rights Journal, 7, 33-86.

Białocerkiewicz, J. (2007). Prawo międzynarodowe publiczne. Zarys wykładu. Toruń: TNOiK.

Borgen, Ch. (2008). Kosovo's Declaration: Analyzing the Legal Issues of Secession and Recognition (2020, February 6). Retrieved from: http://opiniojuris.org/2008/02/20/kosovos-declaration-analyzing-thelegal-issues-of-secession-and-recognition/.

Cassese, A. (2005). International Law. Oxford: Oxford University Press.

Conservation and indigenous peoples' rights. Report to the General Assembly. (2016). (2020, February 6). Retrieved from: http://unsr.vtaulicorpuz.org/site/index.php/documents/annual-reports/149-reportga-2016.

Crawford, J. (1979). The Creation of States in International Law. Oxford: Clarendon Press.

Crawford, J. (2007). The Creation of States in International Law ( $2^{\text {nd }}$ Edition). Retrieved from: http://opil. ouplaw.com/view/10.1093/law/9780199228423.001.0001/law-9780199228423-chapter-9.

Declaration on the Granting of Independence to Colonial Countries and Peoples. (2020, February 6). Retrieved from: http://www.un.org/en/decolonization/declaration.shtml.

Declaration on Principles of International Law concerning Friendly Relations and Co-operation among States in accordance with the Charter of the United Nations. (2020, February 6). Retrieved from: http:// www.un-documents.net/a25r2625.htm.

Declaration on the Rights of Indigenous Peoples. (2007). (2020, February 6). Retrieved from: https://www. un.org/esa/socdev/unpfii/documents/DRIPS_en.pdf.

Dillon, P. \& Bunikowski, D. (2017). “Arguments from Cultural Ecology and Legal Pluralism for Recognising Indigenous Customary Law in the Arctic". In L. Heinämäki \& T. M. Herrmann (Eds.), Experiencing and Protecting Sacred Natural Sites of Sámi and other Indigenous Peoples. The Sacred Arctic (37-64). Cham: Springer.

Ferguson, M. (1999). “Controversy, Change, and the Nisga'a Treaty”. Law Now, 23, 61-69.

Fitzmaurice, M. (2009). “The New Developments Regarding the Saami Peoples of the North”. International Journal on Minority and Group Rights, 16, 67-156.

Gibson, G. (1999). “A Principled Analysis of the Nisga'a Treat”. Public Policy Sources, 27, 1-14.

Gilbert, J. \& Couillard, V. (2009). "Land Rights under international law: historical and contemporary issues". In V. Couillard et al. (Eds.), Land Rights and the Forest Peoples of Africa. Historical, Legal and Anthropological Perspectives (28-48). Moreton-in-Marsh: Forest Peoples Programme.

Gunn, B. (2007). "Protecting Indigenous Peoples' Lands: Making Room for the Application of Indigenous Peoples' Laws Within the Canadian Legal System”. Indigenous Law Journal, 6(1), 31-69. 
Gunn, B. (2011). Understanding and Implementing the UN Declaration on the Rights of Indigenous Peoples: An Introductory Handbook (2020, February 6). Retrieved from: http://quakerservice.ca/wpcontent/ uploads/2011/10/UNDRIP_Handbook_IBA.pdf.

Hoffman, R. \& Robinson, A. (2010). “Nisga'a Self-Government: A New Journey Has Begun”. Canadian Journal of Native Studies, 2, pp. 387-405.

Indigenous Peoples' Seattle Declaration on the occasion of the Third Ministerial Meeting of the World Trade Organization. (1999). (2020, February 6). Retrieved from: http://www.ienearth.org/indigenouspeoples-seattle-declaration/.

International Covenant on Civil and Political Rights. (1966). (2020, February 6). Retrieved from: http:// www.ohchr.org/en/professionalinterest/pages/ccpr.aspx.

Judgment in the case of Reference re Secession of Quebec (2020, February 6). Retrieved from: http://opil.ouplaw.com/view/10.1093/law:ildc/184ca98.case.1/law-ildc184ca98?rskey=3vj7 g0\&result $=5 \&$ prd $=$ ORIL.

Kałduński, M. (2010)., Samostanowienie (Zasada samostanowienia narodów)”. In M. Balcerzak \& S. Sykuna (Eds.), Leksykon ochrony praw człowieka. 100 podstawowych pojęć (441-450). Warsaw: C. H. Beck.

Kari-Oca Declaration and Indigenous Peoples' Earth Charter, World Conference of Indigenous Peoples on Territory, Environment and Development, Kari-Oca 25-30 May 1992 (2020, February 6). Retrieved from: http://www.lacult.unesco.org/lacult_en/docc/Kari-Oca_1992.doc.

Kingsbury, B. (1992). "Claims by Non-State Groups in International Law”. Cornell International Law Journal, 25(3), 481-513.

Koivurova, T. (2008). “The Draft Nordic Saami Convention: Nations Working Together”. International Community Law Review, 10, 279-293.

Loukacheva, N. (2005). On Autonomy and Law (2020, February 6). Retrieved from: https://www.socialsciences.mcmaster.ca/institute-on-globalization-and-the-human-condition/documents/IGHCWOPS_05-3_Loukacheva.pdf.

Magnarella, P. J. (2001-2002). “The Evolving Right of Self-Determination of Indigenous Peoples”. St. Thomas Law Review, 14, 425-447.

Marxsen, Ch. (2014). Crimea's Declaration of Independence. (2020, February 6). Retrieved from: http:// www.ejiltalk.org/crimeas-declaration-of-independence/.

Metcalf, Ch. (2003-2004). “Indigenous Rights and the Environment: Evolving International Law”. Ottawa Law Review, 35, 101-140.

Nisga'a Constitution. (1998). (2020, February 6). Retrieved from: http://www.nisgaanation.ca/legislation/ constitution-nisgaa-nation.

Nisga'a Final Agreement, Chapter 1 (Definitions) (2020, February 6). Retrieved from: http://www.nisgaanation.ca/treaty-documents.

Okafor, O. Ch. (2002). "Entitlement, Process, and Legitimacy in the Emergent International Law of Secession”. International Journal on Minority and Group Rights, 9(1), 41-70.

Report of the Special Rapporteur on the situation of human rights and fundamental freedoms of indigenous people, Rodolfo Stavenhagen. Addendum. Mission to Canada (2004). (2020, February 6). Retrieved from: http://www.gcc.ca/pdf/INT000000012.pdf.

Separate opinion of Judge Cançado Trindade to the ICJ advisory opinion on the Accordance with international law of the unilateral declaration of independence in respect of Kosovo (2020, February 6). Retrieved from: http://www.icj-cij.org/docket/index.php?p1=3\&p2=4\&k=21\& case $=141 \& \operatorname{code}=$ kos $\& \mathrm{p} 3=4$. 
Svensson, T. G. (2002). “Indigenous Rights and Customary Discourse. Comparing the Nisga'a and the Sami”. Journal of Legal Pluralism, 47, 1-35.

UN Charter. (1945). (2020, February 6). Retrieved from: http://www.un.org/en/charter-united-nations/. Understanding the Nisga'a Treaty. (1998). (2020, February 6). Retrieved from: http://www.nisgaanation. $\mathrm{ca} /$ understanding-treaty.

Vidmar, J. (2014). Crimea's Referendum and Secession: Why it Resembles Northern Cyprus More than Kosovo (2020, February 6). Retrieved from: http://www.ejiltalk.org/crimeas-referendum-and-secession-whyit-resembles-northern-cyprus-more-than-kosovo/. 